\title{
SPECIAL FEATURES OF THE FORMING OF THERMAL WATERS OF THE EASTERN PART OF THE KHANGAY NEOTECTONIC UPLIFT
}

\author{
P.S.Badminov ${ }^{1}$, D. Ganchimeg ${ }^{2}$,B.I.Pisarsky ${ }^{l}$,D.Oyuntsetseg ${ }^{2}$ \\ G.I.Orgilyanov ${ }^{1}$, I.G.Kryukova, \\ Ch.Zundui-Osor ${ }^{3}$ \\ ${ }^{I}$ Institute of the earth's crust, RAS, ganchimegdm@yahoo.com \\ 2Institute of chemistry and chemical technology, MAS \\ ${ }^{3}$ MegaWatt Co., Ltd
}

\section{Introduction}

Khangay neotectonic uplift is a large block of the earth's crust confined to the area between two sublatitudinal deep faults (Bulnay and Goby-Altay). They are active faults accommodating main compression stresses in contract to the extension existed in the other area of the Khangay uplift. In contrast to continental rift zones of Khangay it is the region of compression. It is area with the increased values of the heat flux [6].

The eastern part of Khangay hydro-geothermal system is one of the most energetically powerful on the quality of the fluid heat-carrier (temperatures of the geothermal water at ground surface are up to $92^{\circ} \mathrm{C}$ ) with the high yield of thermal sources and on the area of deep magma chamber and high activity of Cenozoic volcanism (Fig.1). Analysis of the temporal-spatial distributions of the volcanic activities manifested in the area indicated that the most heated mantle, capable of magma generation, remains at present precisely under the eastern - Khangay volcanic area [4]. The thermal state of deep subsoil is determined not only by the values of the geothermal parameters obtained during the study of conductive heat flux, but also with the intensity of the convective removal of deep heat by the underground fluids, which are discharged in the form of numerous thermal sources within the zones of active fracturing [6]. 


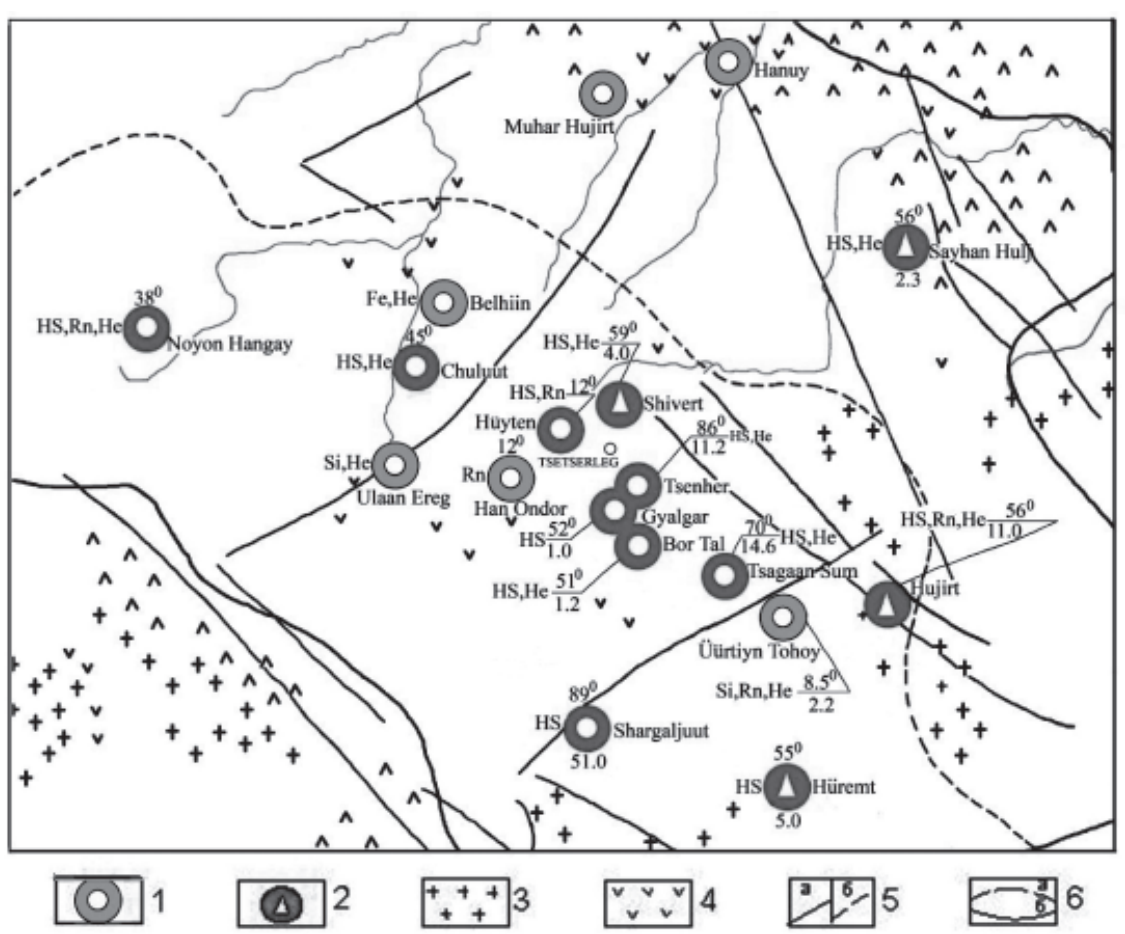

Fig.1. Khangay hydro-geothermal system

(fragment of the map of the mineral waters of Mongolia M 1:2500000)

Centers of upwelling of the nitric siliceous alkaline carbonate sodium hydro-therms: 1- sources, 2- boreholes. Numbers and signs: on top -temperature, ${ }^{\circ} \mathrm{C}$; in the left - the index of balneological active constituent; in the right - the name of the hot springs; below - flow rate or debit, Us. Heat-generating structures: 3- granite plutons; 4- covers of Cenozoic basalts. Water-conducting faults: 5 a- observed; $5 b$-inferred. Boundaries of the Khangay elevation: $6 a$-expressed in the relief; $6 b$-conditional.

\section{Method}

We carried out the gas-geochemical and temperature testing on more than 20 thermal water sources of the eastern part of the Khangay neotectonic uplift for the purpose of obtaining the information about the thermal condition of underground hydrosphere. Temperature measurements do not always make it possible to determine the reasons for thermal anomaly and influence of exogenous and endogenous factors [5]. Estimation of the roles of these factors is possible, if exist data on temperature condition in the thermal water table at the depth. Most precise data on "base temperatures" can be obtained by direct measurements of temperatures in the deep boreholes; however, we do not possess such information. On the other hand, the temperature condition of the water table at depth can be estimated by indirect methods, using hydro-geochemical geothermometers 
[7, 8 and 10]. For calculations we have used the silica geothermometer, which had shown satisfactory results in the determination of "base temperatures" of nitric thermal water of Baikal rift zone [2].

Silica geothermometer is based on the correlation of temperature with the concentration of $\mathrm{SiO}_{2}$; however, the solubility of silica depends not only on temperature but also on other factors such as forms of silica. V.N. Disler [3] examined the behavior of various forms of silicon both in the water and in minerals for different P-T conditions. Based on the regression curves (Fig 2) obtained in result of the experiment, he classified thermal waters into types. Regression curves shown in fig 2 are composition and temperature dependent parameters, and so far calculated temperature for each line have been performed with taking account into forms of silicon compounds.

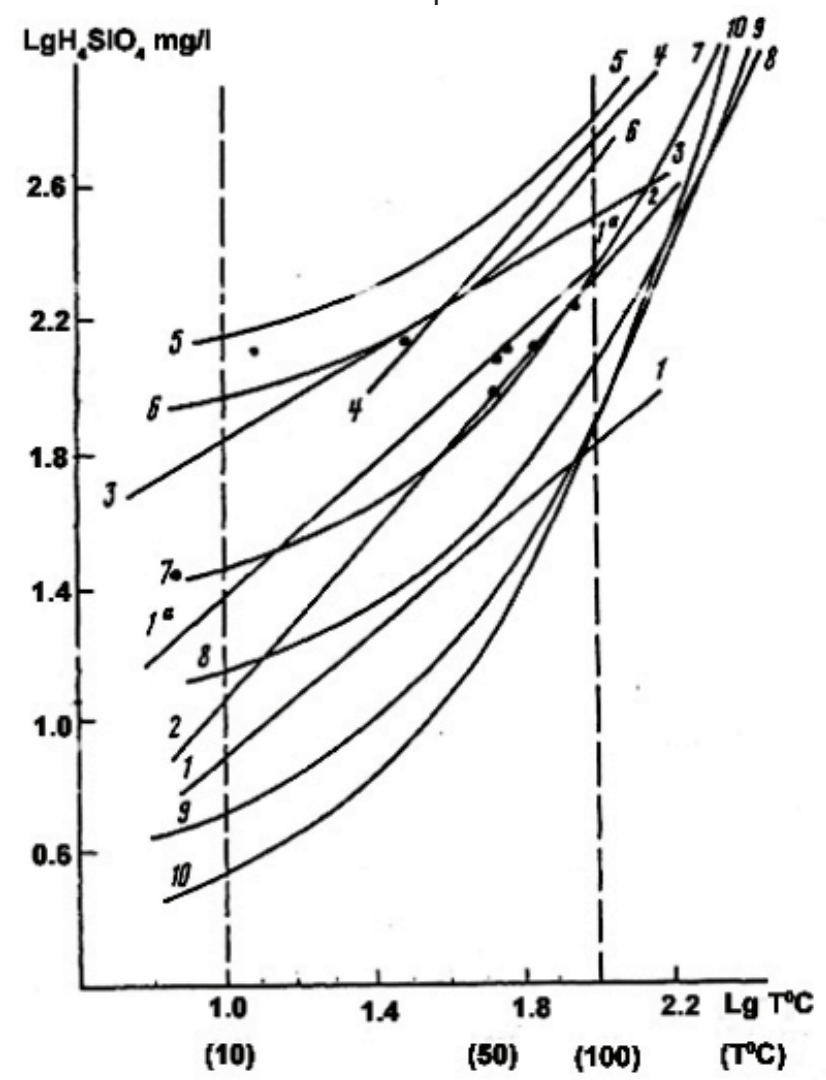

Fig.2. Graphic expression of regression equations $\mathrm{Ig} \mathrm{H}_{4} \mathrm{SiO}_{4}(\mathrm{mg} / \mathrm{l})$ for $\operatorname{lg~}^{\circ} \mathrm{C}$ (on Disler V. N, 1987)

Regression lines: 1- nitric, nitric-methane and methane waters of sediment; 1a-carbonate water of sediment; 2 - nitric thermal water of the ejected and volcanogenic-sediment; 3- carbonate water of the igneous rocks; 4-fumaroles thermal water; Solubility of various forms of $\mathrm{SiO}_{2}{ }_{2}$ in the conversion on $\lg \mathrm{H}_{4} \underline{\mathrm{SiO}}_{4}(\mathrm{mg} / \mathrm{l})$ : 5 - amorphous 
silica; 6- $\beta$-cristobalite; 7- $\alpha$-cristobalite; 8 - chalcedony; 9-quart during the adiabatic cooling; 10 - quart during the conductive cooling. Points-actual data on the mineral waters Khangay.

Predicted temperatures of water table at depth in accordance with silica geothermometer in the low-temperature systems Khangay $\left(\mathrm{t}_{\text {sur }}<\mathrm{t}_{\text {boil }}\right)$

$\begin{array}{lcccccc}\text { № } & \text { Deposit } & \mathbf{T}_{\text {sur }} & \mathbf{H}_{4} \mathbf{S i O}_{4} & \mathbf{S i O}_{2} & \begin{array}{c}\text { Tdeep. fore- } \\ \text { cast. }\end{array} & \begin{array}{c}\mathbf{H}_{\text {formation }} \\ \mathbf{t}_{\text {deep }} / \boldsymbol{\gamma}\end{array} \\ 1 & \text { Shivert } & 57 & 145,5 & 97 & 120,8 & 4,83 \\ 2 & \text { Khuyten-arshan } & 12,5 & 131,07 & 87,38 & 114,1 & 4,56 \\ 3 & \text { Tsenkher } & 84 & 178,57 & 119,05 & 134,4 & 5,37 \\ 4 & \text { Bor tal } & 52 & 98,05 & 65,37 & 97 & 3,88 \\ 5 & \text { Gyalgar } & 52 & 121,95 & 81,3 & 109,8 & 4,39 \\ 6 & \text { Tsagaan sum } & 69,1 & 133 & 88,7 & 115,1 & 4,61 \\ 7 & \text { Gants mod } & 4 & 28,57 & 19,05 & 38,3 & 1,53 \\ 8 & \text { Saykhan Khulj } & 57 & 104 & 69,36 & 100,4 & 4,01 \\ 9 & \text { Khanuy } & 3 & 54 & 36,01 & 66,0 & 2,64 \\ 10 & \text { Khan undur } & 2,6 & 44 & 29,34 & 56,6 & 2,26 \\ 11 & \text { Mukhar khujirt } & 3,2 & 33 & 22,01 & 44,2 & 1,77 \\ 12 & \text { Belkh } & 5,4 & 35 & 23,34 & 46,6 & 1,86 \\ 13 & \text { Angarkhay } & 0,8 & 34 & 22,67 & 45,4 & 1,81 \\ 14 & \text { Chuluut } & 45,2 & 100 & 66,69 & 98,1 & 3,93 \\ 15 & \text { Ulaan ereg } & 13,5 & 57 & 38,01 & 68,7 & 2,75 \\ 16 & \text { Noyon khangay } & 36,4 & 130 & 86,70 & 113,7 & 4,55 \\ 17 & \text { Shargaljuut } & 88-92 & 154 & 102,70 & 124,5 & 4,98 \\ 18 & \text { Khujirt } & 47 & 144 & 96,04 & 120,1 & 4,80 \\ 19 & \text { Khuremt } & 55,5 & 133 & 88,70 & 115,1 & 4,61 \\ 20 & \text { Uurtiin tokhoy } & 10,5 & 74,1 & 49,42 & 81,8 & 3,27\end{array}$

\section{Results and discussion}

Data on silica dioxide contents in the water of thermal sources Khangay have been plotted on the solubility curve of $\alpha$ - cristobalite. Then, evaluations of predicted temperatures are made according to Fournier-Trusdel formula for the low-temperature systems of $\mathrm{t}_{\text {sur }}<\mathrm{t}_{\text {boil }}$. The results are shown in table.

$$
T_{\text {deep }}=\frac{1051.1}{4.655-\text { LogSiO }_{2}}-273.15
$$

The values of temperatures of water table at depth and average geothermal gradient $y=25^{\circ} \mathrm{C} / \mathrm{km}$., accepted for this region [1] make it possible to estimate the depth of formation of hydro-therm. They are within of $4-5 \mathrm{~km}$. 
This is confirmed by geophysical data of Mordvinova, which revealed powerful heated plume at the large depths caused by the ascending of asthenospheric mantle to earth's crust, but the small thermal bodies at the depths of 4-5 km, which appears in geophysical section have been distinguished, according to the data of teleseismic signals "Mobal 2003" [9].

Predicted temperatures of the formation of hydro-therm at the depth (tabl.) are considerably high, however, during the upwelling, the temperature of the gas-liquid heatcarrier goes down due to mixing with underground water and warming up the surrounding rocks etc. According to the published information these losses usually are within 30 -50 percent. Furthermore for the calculations of the depth of the formation of the hydrotherm, same geothermal gradient used for conductive heat flux have been used. We are dealing with the convective flow, and consequently the geothermal gradient is higher.

Based on the obtained results, the 6 potential areas have been isolated for further studies with purpose of geothermal energy usage. The vertical electrical sounding have been conducted on two of them (Shivert and Tsenkher) end the promising areas have been contoured.

The geophysical studies (VES) conducted on Shivert area near the basic output of hydro-therm (fig.3), have shown that the earth crust with the lowered value of resistances is available in the sections of apparent resistances sections of VES 6 and 7 up to the depth of 40 meters. The curve VES 10 is obtained at a distance of $25 \mathrm{~m}$ from the acting source. Within a source at a depth of $40 \mathrm{~m}$ electrical resistivity is in the range 10-20 $\mathrm{om} \cdot \mathrm{m}$ (VES 10) and in section 6, the VES increased to $50-100 \mathrm{om} \cdot \mathrm{m}$. This it can testify about the increased mineralization and the temperature of ground water.

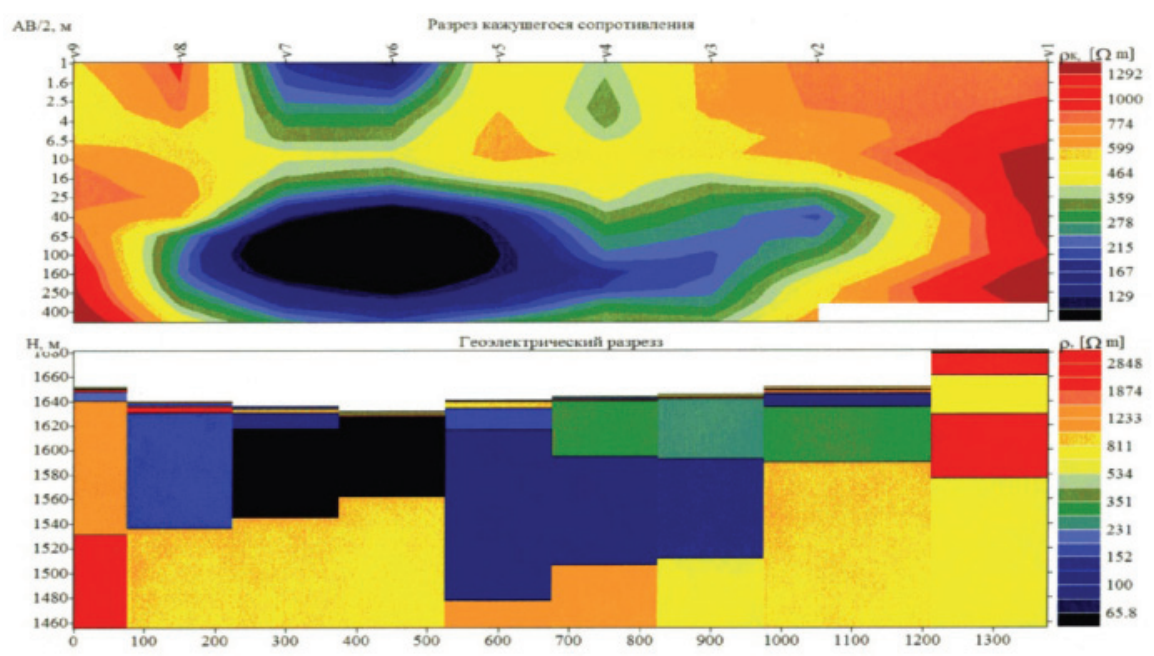

Fig.3. Section of apparent resistances and the geoelectric section of thermal water deposit of Shivert 
In 2009 drill hole of $78 \mathrm{~m}$ deep had been performed at the section of Shivert, near the basic source. For the selection of the appropriate places for exploration boreholes, the broad data analysis, obtained not only under our expedition, but also under previous exploration work carried out by mineral water division of Mineral resources authority of Mongolia in Ulaanbaatar, have been performed using widely known methods (chemical, gaseous, geothermal, vertical electrical sounding), and also the newest procedures (geochemical geothermometers, isotopic studies, land survey, ICP-MS) [1].

The drilled borehole (2-gr) at chosen places has revealed thermo with the maximum temperature of $+66.9^{\circ} \mathrm{C}$ for this deposit. Schematic hydro-geological and geothermal section the valley of river Shivert have shown in fig.4.

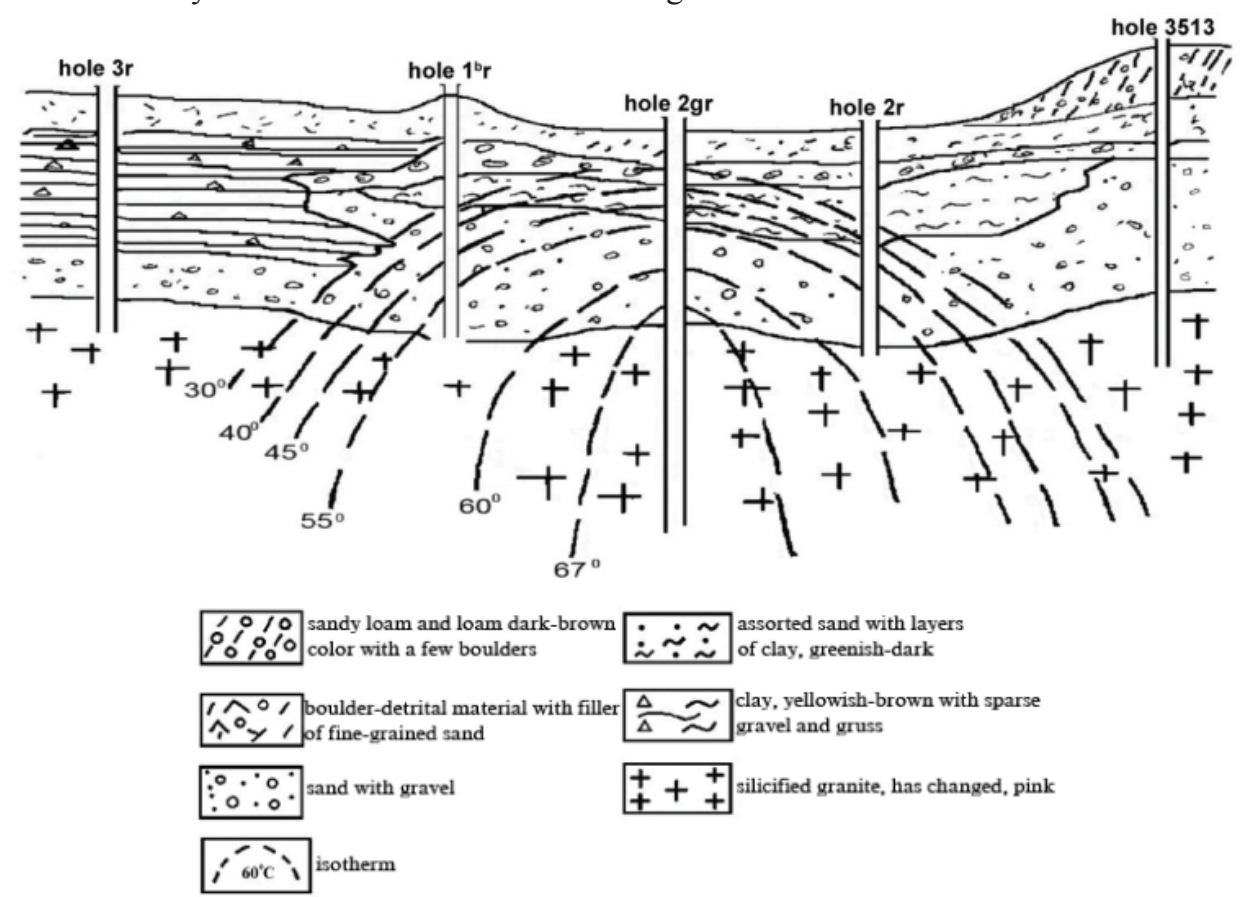

Fig.4. Hydro geological and geothermal section of stretch of the valley of river Shivert

Upwelling thermal waters occurs through the sand-gravel deposit, therefore maximum temperature is achieved at the depth of bedrock - $33 \mathrm{~m}$.

The result of the performed works on Shivert deposit, allow assuming the presence of geothermal sources at the depth of up to $1 \mathrm{~km}$ with the temperature of gas-aqueous solution of $130-150^{\circ} \mathrm{C}$. For determining the precise depth of geothermal source, it is necessary to conduct the additional geophysical survey (gravimetric reconnaissance) penetrating to the depth of $2 \mathrm{~km}$. Vertical electrical sounding is effective for small depths up to $100 \mathrm{~m}$, and teleseismic signals covers too great depths, that is beyond of the earth's crust (tens of kilometers). 


\section{Conclusions}

High temperatures of the underground hydrosphere of east Khangay area are related to deep magmatogenic thermo-anomaly; consequently it could have enormous practical interest. Linked to this, the region can be recommended as potential area for using the geothermal energy not only for municipal service system, but also for the electric energy generation (minimum necessary temperature for this purposes are $130^{\circ} \mathrm{C}$ with the debit $5-6 \mathrm{l} / \mathrm{s}$ ). The calculated depths of formation of hydro-therm are within the $4 \mathrm{~km}$; however, their real values could be considerably less if we take account into heat losses during the ascending through rock-column and mixing with the meteoric waters etc.

\section{References}

1. Badminov P.S., Pisarsky B.I., Orgilyanov A.I., Nambar B., Ganchimeg D., Kryukova I.G., Ivanov A.I. Prospects for the use of thermal waters Khangay // Spa resources of the BaikalMongolian region and rehabilitation medicine, Ulaanbaatar, 2008.- p. 53-56. (in Russian)

2. Golubev V.A. Thermal and chemical characteristics of hydrothermal systems of the Baikal rift zone // Geochemistry, №10. 1982. -p.100-108. (in Russian)

3. Disler V.N. Silica in the underground hydrosphere //The origin and the practical use of siliceous rocks, Moscow, 1987. - p. 128-140. (in Russian)

4. Zorin Y.A., Turutanov E.X., Kojevnikov V.M., Rasskazov S.V., Ivanov A.I. The nature of cenozoic upper mantle plumes in East Siberia (Russia) and Central Mongolia //Geology and geophysics, vol.47, №10, 2006.- p.1060-1074. (in Russian)

5. Lavrushin V.Y., Makovozov A.O. The temperature of mineral water - a reflection of magmatic thermal anomalies in the vicinity of the volcano Kazbek // Journal of Vladikavkaz Scientific Center, vol.4, №3, 2004.- p.33-40 (in Russian)

6. Lisak S.V., Dorofeeva R.P. The thermal state of the lithosphere in Mongolia // Geology and geophysics, vol.44, №9, 2003. - p. 929-941. (in Russian)

7. Fournier R.O., Truesdell A.H. An empirical Na-K-Ca chemical geothermometer for natural waters // Geochim. Et Cosm. Acta. 1973. V. 37. - P. 1255-1275

8. Kharaka Y.K., Mariner R.N. Chemical Geothermomethers and Their Application to Formation Waters from Sedimentary Basins. In.: Thermal History of Sedimentary Basins, Methods and Case Histiries. New York: Spring.-Verlag, 1989.-P. 99-117

9. Mordvinova V.V., Deschamps A., Deverchere J. et al. Velocity structure of the lithosphere on the Siberian platform - Goby-Altai profile on the base of teleseismic experiment "MOBAL 2003" // Active geophysical monitoring of the lithosphere of the earth, Novosibirsk, 2005.- p. 223-227.

10. Philip H., Cisternas A., Gvishniani A., Gorshkov A. The Caucasus: an actual example of the inin-tial stages of continental collision // Tectonophysics, 1989. V.161. - P. 1-21. 